\title{
Comparison of Glucosinolate Profiles in Leaf and Seed Tissues of Different Brassica napus Crops
}

\author{
Pablo Velasco', Pilar Soengas, Marta Vilar, and Maria Elena Cartea \\ Department of Plant Genetics, Misión Biológica de Galicia (CSIC), Apartado 28, \\ E-36080 Pontevedra, Spain

\begin{abstract}
Mercedes del Rio
Department of Agronomy and Plant Breeding, Instituto de Agricultura Sostenible (CSIC), Alameda del Obispo s/n, E-14080 Córdoba, Spain
\end{abstract}

\begin{abstract}
Additional INDEX WORDs. glucobrassicanapin, gluconapin, leaf rape, forage rape, oilseed rape, root vegetables
Abstract. The glucosinolate profile of leaves and seeds of 33 Brassica napus $\mathbf{L}$. crops, including leafy crops, forage, rutabaga, and oilseed crops, was compared by high-performance liquid chromatography to investigate the relation between the consumable product of each crop and the glucosinolate profile. Glucosinolate concentration was higher in seeds than in leaves, varying from 3.8-fold in oilseed crops to 7.1-fold in root vegetable crops. Aliphatic glucosinolates predominated in both organs. In seeds, aliphatic glucosinolates represented between $91 \%$ to $94 \%$ in the different groups, whereas in leaves there was more variation. For root vegetable crops, aliphatic glucosinolates represented $\mathbf{8 0} \%$ of the total glucosinolate concentration. For leafy and forage types, aliphatic glucosinolates represented approximately $90 \%$ and for oilseed crops represented $92 \%$. Indole glucosinolates were more abundant in leaves $(5 \%$ to $17 \%$ ) than in seeds (5\% to $8 \%$ ). The total glucosinolate content in leaves ranged from 14 to $24 \mu \mathrm{mol} \cdot \mathrm{g}^{-1} \mathrm{dry}$ weight (DW) in oilseed and forage types, respectively, whereas in the seeds, it ranged from 55 to $115 \mu \mathrm{mol} \cdot \mathrm{g}^{-1} \mathrm{DW}$ in oilseed and forage types, respectively. Significant differences were noted among the four groups in glucosinolate concentration and glucosinolate composition. In the seeds, progoitrin was found as the main glucosinolate in all groups. In the leaves, two different glucosinolate profiles were found depending on the crop: forage and root vegetable crops showed high levels of progoitrin, whereas glucobrassicanapin was the main glucosinolate for oilseed and leafy crops. We suggest that different selection criteria applied on $B$. napus crops according to their use could have led to an indirect selection for glucosinolate profile in leaves.
\end{abstract}

Glucosinolates are secondary plant metabolites that occur naturally in Brassicaceae, a plant family that has given rise to important crops such as oilseeds (Brassica napus) and cabbages (Brassica oleracea). Based on the amino acid origin of the side chain, glucosinolates are divided into aliphatic, aromatic, and indole glucosinolates, which are derived from methionine, phenylalanine, and tryptophan, respectively. After tissue damage, glucosinolates may undergo enzymatic hydrolysis by the myrosinase enzymes (thioglucohydrolase, E.C. 3.2.1.147) to yield a variety of biologically active products, including nitriles, thiocyanates, and isothiocyanates, depending on the reaction conditions and presence of associated proteins (Fenwick et al., 1983; Lambrix et al., 2001). These products have a wide range of biological activity, which include both positive and negative nutritional attributes and effects on the attraction, growth, and survival of plant-herbivores (Cartea and Velasco, 2008; Wittstock and Gershenzon, 2002). The consumption of Brassica L. crop species has been linked with reduced risk of cancers, and this protective role has been associated with the ability of the glucosinolate hydrolysis products to activate protective mechanisms within the body. The anticarcinogenic properties of some isothiocyanates and indole glucosinolates

Received for publication 5 Feb. 2008. Accepted for publication 3 Apr. 2008. This research was supported by the Committee for Science and Technology of Spain (Project Cod. AGL2006-04055) and Excma. Diputación Provincial de Pontevedra, Spain.

We acknowledge the invaluable help of Elisa Santiago and Rosaura Abilleira for all of their laboratory work.

${ }^{1}$ Corresponding author. E-mail: pvelasco@mbg.cesga.es. have been described in detail in many reviews (Cartea and Velasco, 2008; Fahey et al., 2001; Fenwick et al., 1983; Rosa et al., 1997).

Conversely, glucosinolates have been shown to have a deleterious effect on domesticated livestock when consumed at high concentrations (Fenwick et al., 1983; Griffiths et al., 1998; Laurberg et al., 2002). This is largely due to the presence of progoitrin, which accumulates in the seeds of oilseed rape [B. napus var. oleifera (Delile) Sinskaya] and which degrade to give goitrogenic products (Griffiths et al., 1998). For this reason, oilseed rape cultivars with low seed glucosinolate contents (canola type) were obtained by selective breeding (Rosa et al., 1997). Nevertheless, there is no evidence for any goitrogenic effect on humans from brassica consumption (Mithen, 2001).

Brassica napus L. includes economically important crops such as oilseed rape grown for seeds, rutabaga [B. napus var. rapifera (Metzg) Sinskaya] grown for its enlarged swollen hypocotyls, and leaf rape [B. napus var. pabularia (DC.) Rchb.] such as siberian kale or hanover salad, grown for leafy greens in northern Europe. Crops of this last group are highly appreciated for human consumption in northwestern Spain and northern Portugal where they are known as "nabicol" and "couvenabiça," respectively (Cartea et al., 2008; Font et al., 2005).

Many studies have determined glucosinolates in seeds, and to a lesser extent, in leaves of Brassica species (Fahey et al., 2001) where these compounds are also present although at lower concentrations than those usually found in the seeds. Less attention has been paid to glucosinolate composition of crops 
such as leaf rape, rape kale, or forage rape, of which the leaf tissue are consumed. The glucosinolates in these crops are responsible for the characteristic pungent taste, which is highly appreciated by humans. Moreover, current interest is focused on the anticarcinogenic activity of isothiocyanates found in leaves of vegetable crops.

Among the metabolic compounds which have frequently been used as chemical markers in chemotaxonomy, the glucosinolates stand out, and it is well known that their distribution in Brassica crops is diverse and varies among species and among crops from the same species. In fact, the presence of glucosinolates has been suggested as an important chemotaxonomic criterion for classification within the Brassicaceae family (Heaney and Fenwick, 1980). In B. napus cultivars, artificial selection is aimed at different plant organs (seeds, roots, stems, and leaves). Artificial selection may also have changed the quality and quantity of glucosinolates in each of the crop cultivars. The glucosinolate pattern in leaves and seeds of several B. napus crops has been reported (Cartea et al., 2008; Fenwick et al., 1983; Griffiths et al., 2001; Hopkins et al., 1998). However, the variation in glucosinolate content has not been related to the consumable product of the crop.

The aim of this study was to determine the diversity of glucosinolate content and profiles in leaves and seeds of $B$. napus crops with different end uses.

\section{Materials and Methods}

Plant material. Thirty-three $B$. napus cultivars from different geographic origins were included in this study (Table 1). Cultivars were divided into four groups (forage, leafy, oilseed, and root vegetable crops) based on the end use of the

Table 1. List of Brassica napus cultivars included in the study of glucosinolate profile.

\begin{tabular}{|c|c|c|c|c|}
\hline Cultivars & Origin & Common name & Type ${ }^{z}$ & $\begin{array}{c}\text { Seed } \\
\text { source }^{\mathrm{y}}\end{array}$ \\
\hline \multicolumn{5}{|l|}{ Forage crops } \\
\hline BE053 (Ragged Jack kale) & New Zealand & Rape kale & $\mathrm{C}$ & $\mathrm{CGN}$ \\
\hline BE072 (Rape kale) & UK & Rape kale & $\mathrm{C}$ & HRI \\
\hline BE051 (Colza Rocalba) & Spain & Forage rape & $\mathrm{C}$ & MBG \\
\hline BE054 (Vysokopol'skij) & Russia & Forage rape & $\mathrm{C}$ & $\mathrm{CGN}$ \\
\hline \multicolumn{5}{|l|}{ Leafy crops } \\
\hline MBG-BRS0014 & Spain & Nabicol & $\mathrm{L}$ & MBG \\
\hline MBG-BRS0039 & Spain & Nabicol & $\mathrm{L}$ & MBG \\
\hline MBG-BRS0054 & Spain & Nabicol & $\mathrm{L}$ & MBG \\
\hline MBG-BRS0063 & Spain & Nabicol & $\mathrm{L}$ & MBG \\
\hline MBG-BRS0113 & Spain & Nabicol & $\mathrm{L}$ & MBG \\
\hline BE002 (Nabicol Rocalba) & Spain & Nabicol & $\mathrm{C}$ & MBG \\
\hline BE006 & Portugal & Couve-nabiça & $\mathrm{L}$ & HRI \\
\hline BE013 & Portugal & Couve-nabiça & $\mathrm{L}$ & HRI \\
\hline BE014 & Portugal & Couve-nabiça & $\mathrm{L}$ & HRI \\
\hline BE015 & Portugal & Couve-nabiça & $\mathrm{L}$ & HRI \\
\hline BE030 & Portugal & Couve-nabiça & $\mathrm{L}$ & HRI \\
\hline BE031 & Portugal & Couve-nabiça & $\mathrm{L}$ & HRI \\
\hline BE033 & Portugal & Couve-nabiça & $\mathrm{L}$ & HRI \\
\hline BE038 & Portugal & Couve-nabiça & $\mathrm{L}$ & HRI \\
\hline \multicolumn{5}{|l|}{ Oilseed crops } \\
\hline MBG-BRS0388 (C. Santos) & Portugal & Winter oilseed rape & $\mathrm{C}$ & MBG \\
\hline BE064 (Friese Gele) & The Netherlands & Rutabaga & $\mathrm{C}$ & $\mathrm{CGN}$ \\
\hline BE058 (Lollo) & Germany & Rutabaga & $\mathrm{C}$ & CGN \\
\hline
\end{tabular}

${ }_{\mathrm{z}} \mathrm{L}=$ landrace, $\mathrm{C}=$ commercial.

${ }^{\mathrm{y}} \mathrm{CGN}=$ Center for Genetic Resources, Wageningen, The Netherlands; MBG = Misión Biológica de Galicia, Pontevedra, Spain; HRI = Horticulture Research International, Wellesbourne, UK. 

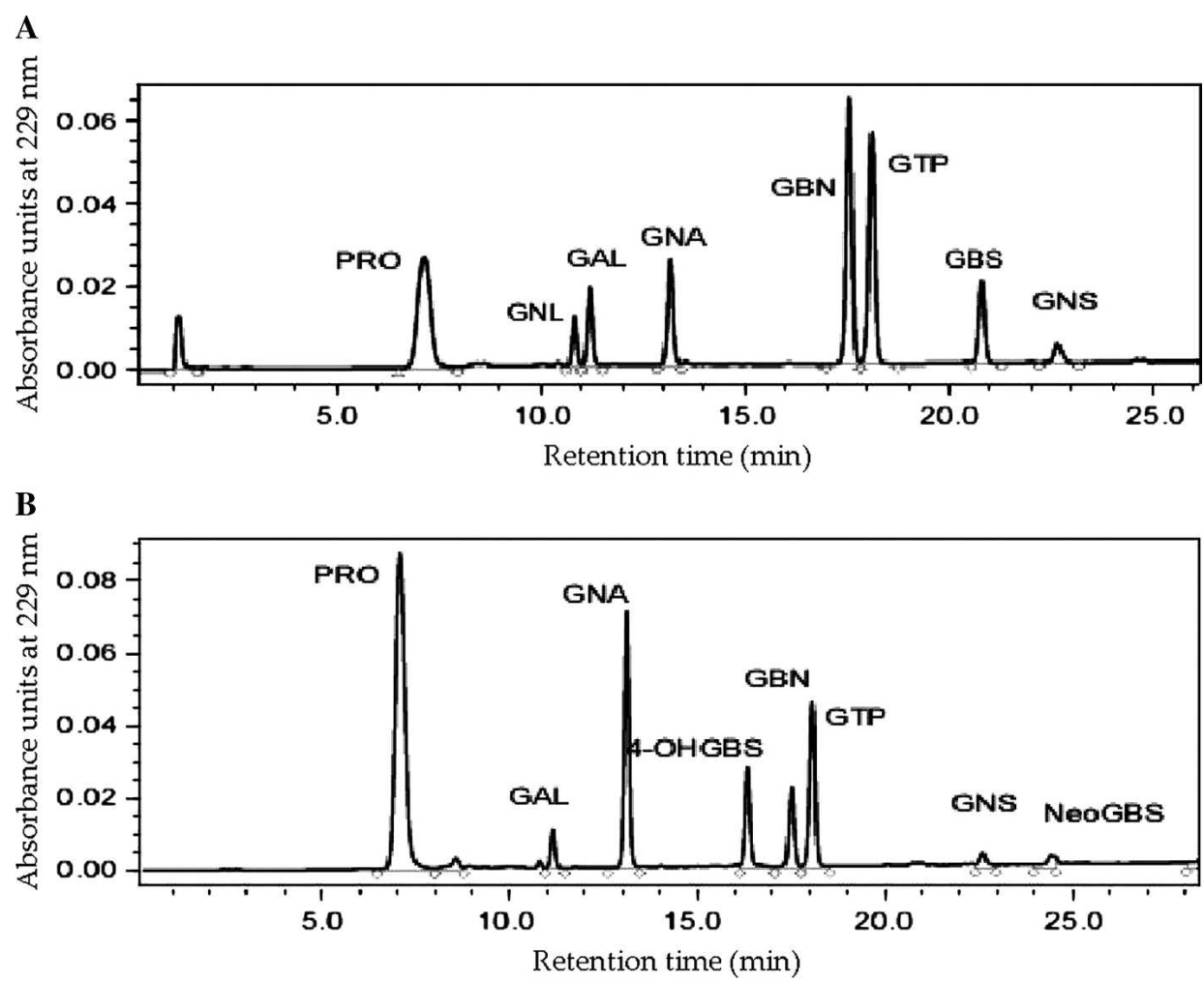

Fig. 1. Typical HPLC chromatograms of glucosinolates detected in leaves (A) and seeds (B) of Brassica napus crops with glucotropaeolin as internal standard measured at $229 \mathrm{~nm}$. PRO $=$ progoitrin, $\mathrm{SIN}=$ sinigrin, $\mathrm{GNL}=$ gluconapoleiferin, $\mathrm{GAL}=$ glucoalyssin, $\mathrm{GNA}=$ gluconapin, $\mathrm{GBN}=$ glucobrassicanapin, $\mathrm{GBS}=$ glucobrassicin, OHGBS $=4$-hydroxyglucobrassicin, $\mathrm{NGBS}=$ neoglucobrassicin, and GNS $=$ gluconasturtiin.

transplanting. The five upper leaves per plant (the two next to the apical leaf along with the adjacent three leaves) were sampled because they are the tender leaves used for human consumption. Leaf samples were frozen in situ and were taken immediately into the laboratory where they were stored at $-80^{\circ} \mathrm{C}$. The leaf samples were then ground in liquid $\mathrm{N}_{2}$, freeze-dried, and milled to a fine powder for the glucosinolate extractions. At seed harvest, a sample of siliques was collected from 10 plants randomly selected from each plot; the middle part of the inflorescence raquis was used and 20 siliques per plant were randomly chosen. The seeds were dried at $90{ }^{\circ} \mathrm{C}$ for $24 \mathrm{~h}$ and were ground into a fine powder in a paint shaker by high agitation.

The purification technique followed the basic sephadex/sulfatase arabidopsis [Arabidopsis thaliana (L.) Heynh] protocol previously described by Kliebenstein et al. (2001) with minor modifications. Samples were harvested into deepwell microtiter tubes (about $10 \mathrm{mg}$ of freeze-dried leaf material or 5-8 $\mathrm{mg}$ of dried seeds). To extract glu-

material. The first group was formed by three cultivars of forage rape and three of rape kale from diverse geographic origin. The second group was formed by eight nabicol landraces and eight couve-nabiças landraces, along with two commercial cultivars of nabicol. Nabicol landraces are from northwestern Spain and were chosen based on previous morphological and molecular characterizations (Cartea et al., 2005; Rodríguez et al., 2005). Cultivars of couve-nabiça are from Portugal and were chosen to represent different geographic and climatic conditions in that country. The third group included six oilseed rape cultivars, comprising spring and winter canola. The fourth group included three rutabaga cultivars (Table 1 ).

Leaves and seeds were harvested from the experimental fields described in Soengas et al. (2008) for glucosinolate analyses. The trials comprised the 33 cultivars above described and were performed at two locations: Pontevedra, Spain (lat. $42^{\circ} 24^{\prime} \mathrm{N}$, long. $8^{\circ} 38^{\prime} \mathrm{W}$, altitude $50 \mathrm{~m}$ ) and Valongo, Spain (lat. $42^{\circ} 26^{\prime} \mathrm{N}$, long. $8^{\circ} 27^{\prime} \mathrm{W}$, altitude $500 \mathrm{~m}$ ). Seeds were sown in multipot trays and seedlings were transplanted into the field at the five- to six-leaf stage, around $45 \mathrm{~d}$ after sowing. Transplanting dates were on 30 Sept. in Pontevedra and on 13 Oct. in Valongo. Cultivars were evaluated in a randomized complete block design with three replications at each location. Each experimental plot consisted of two rows with 10 plants per row. Rows were spaced $0.9 \mathrm{~m}$ apart and plants within rows were $0.6 \mathrm{~m}$ apart. Cultural operations, fertilization, and weed control were made according to local practices.

Glucosinolate EXTRACTION AND PURIFICATION. In each replication, a sample of healthy, fresh leaves was collected from three to five plants from each plot 4 months after cosinolates, $400 \mu \mathrm{L}$ of methanol, $10 \mu \mathrm{L}$ of $0.3 \mathrm{M}$ lead acetate, $120 \mu \mathrm{L}$ of water, and $12 \mu \mathrm{L}$ of glucotropaeolin as internal standard were added. To desulfate glucosinolates on the column, $10 \mu \mathrm{L}$ of water and $10 \mu \mathrm{L}$ of sulfatase (Sigma-Aldrich, St. Louis) solution were added to each column and the plates were incubated overnight at room temperature. Desulfo-glucosinolates were eluted with $100 \mu \mathrm{L}$ of $60 \%$ (by volume) methanol and twice with $100 \mu \mathrm{L}$ of water. This experiment was performed five times for each sample and the extracts were used for the separation and identification of the glucosinolates.

GLuCOSINOLATE IDENTIFICATION AND QUANTIFICATION. Twenty microliters of the glucosinolate extract was used to identify and quantify the glucosinolates. The chromatographic analyses were carried out on a high-performance liquid chromatograph (HPLC; Waters, Milford, MA) equipped with a 2695 Waters Separations Module and a 996 Waters photodiode array detector. The HPLC column was a C18 Waters Symmetry Shield RP18 (5- $\mu \mathrm{m}$ particle size, $150 \times 4.8 \mathrm{~mm}$ i.d.) and was protected with a C18 guard column (Waters). The oven temperature was set at $30{ }^{\circ} \mathrm{C}$. Compounds were detected at $229 \mathrm{~nm}$ and were separated using the following program for leaves and seeds in aqueous acetonitrile, with a flow of 0.8 $\mathrm{mL} \cdot \mathrm{min}^{-1}$ : Three minutes at $100 \% \mathrm{H}_{2} \mathrm{O}$, a 23 -min gradient from $0 \%$ to $25 \%(\mathrm{v} / \mathrm{v})$ acetonitrile, $1 \mathrm{~min}$ at $25 \%(\mathrm{v} / \mathrm{v})$ acetonitrile, a 9 -min gradient from $25 \%$ to $0 \%(\mathrm{v} / \mathrm{v})$ acetonitrile, and a final $4 \mathrm{~min}$ at $100 \% \mathrm{H}_{2} \mathrm{O}$. Data were recorded on a computer with the Millenium32 software (Waters). The type and amount of glucosinolates were estimated based on certified glucosinolate levels of three certified reference materials recommended by U.E. and ISO (CRMs 366, 190, and 367; Wathelet et al., 1991). 
Statistical analysis. A combined analysis of variance across locations was made. Cultivars were considered as fixed factors, whereas locations, replications and the location $\times$ cultivar interaction were considered as random factors. Comparisons of means were performed for each trait using Fisher's protected least significant difference (LSD) at $P=0.05$ (Steel et al., 1997). The sums of squares for cultivars and for the genotype $\times$ location interactions were orthogonally divided into components according to four groups (forage, leafy, oilseed, and root vegetable crops) described in Table 1. For those traits for which cultivar $\times$ location interactions were significant, individual analyses of variance at location were accomplished. Analyses were made using the GLM procedure of SAS (version 9; SAS Institute, Cary, NC). Simple correlations among seed and leaf glucosinolates were made using the Corr procedure of SAS.

\section{Results and Discussion}

Twelve glucosinolates were detected in leaves and seeds of B. napus crops belonging to the three chemical classes: seven aliphatic (progoitrin, epiprogoitrin, sinigrin, gluconapoleiferin, glucoalyssin, gluconapin, and glucobrassicanapin), four indole (glucobrassicin, 4-hydroxyglucobrassicin, neoglucobrassicin, and 4-methoxyglucobrassicin), and one aromatic (gluconasturtiin). Glucosinolate concentration was higher in seeds than in leaves, varying from 3.8-fold in oilseed crops to 7.1-fold in root vegetable crops. Aliphatic glucosinolates predominated in both organs. In seeds, aliphatic glucosinolates represented between $91 \%$ to $94 \%$ of the total glucosinolate content in the different groups, while in leaves there was more variation: for root vegetable crops, aliphatic glucosinolates were $80 \%$ of the total glucosinolate concentration. In leafy and forage types aliphatic glucosinolates represented around $90 \%$ and in oilseed crops they represented $\approx 92 \%$. Indole glucosinolates were more abundant in leaves (5\% to $17 \%$ ) than in seeds $(5 \%$ to $8 \%)$. The typical HPLC chromatograms of glucosinolates detected in seeds and leaves are showed in Fig. 1.

The B. napus cultivars in this study were divided into four groups based on their consumable product. Concentrations of most of the individual glucosinolate compounds as well as totals differed significantly among the four groups in seeds and leaves (Table 2).

LEAVES. Regarding the individual glucosinolates found in leaves, the groups differed significantly for all of them $(P<$ 0.05 ), except for two aliphatic glucosinolates (sinigrin and glucoalyssin) and one indole glucosinolate (4-hydroxyglucobrassicin). The location $\times$ group interaction significantly affected the concentration of the total glucosinolates in leaves. In the individual analysis by location, there were significant differences among groups $(P<0.01)$ at Pontevedra and Valongo. In Pontevedra, forage and leafy groups had the highest glucosinolate content and there were no significant differences among oilseed and root vegetable crops. In Valongo, leafy crops had the highest glucosinolate content and there were no significant differences among the other three types. The location $\times$ group interaction did not significantly affect the concentrations of the individual glucosinolates, suggesting that glucosinolate content of aliphatic, indole, and aromatic glucosinolates of each group was not influenced by the environment. Previous studies suggest that indole glucosinolates are more sensitive to environmental effects and less to the

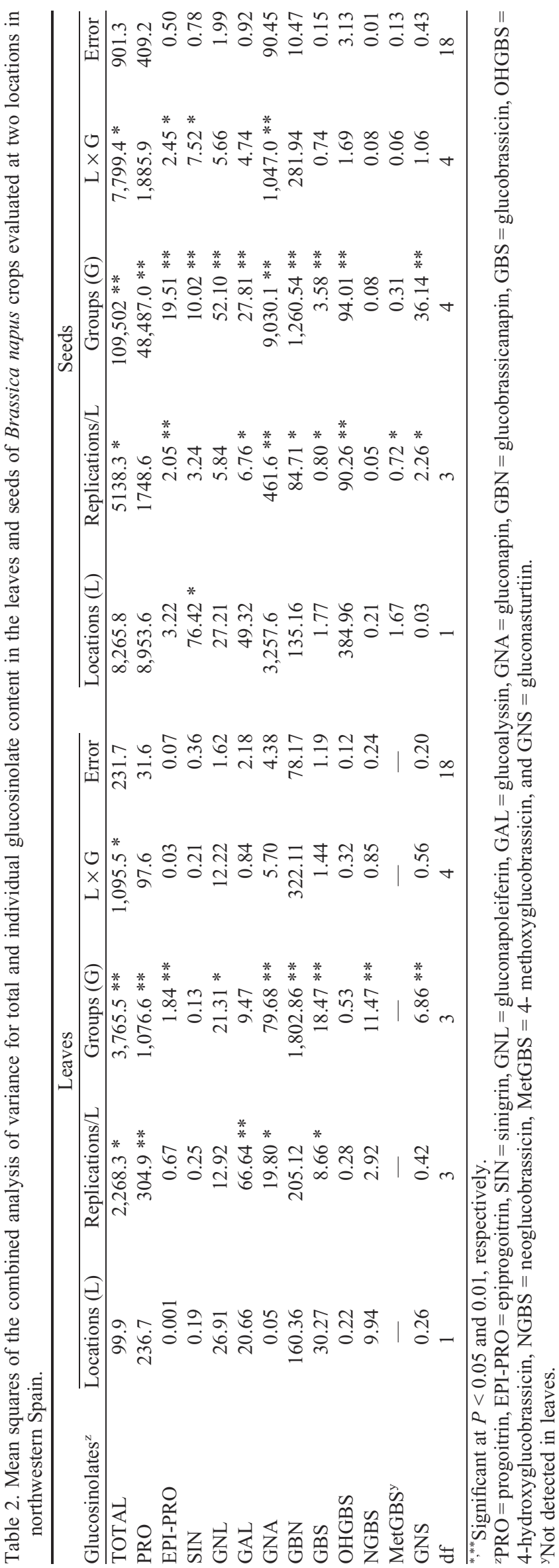


genotype than aliphatic glucosinolates (Kim et al., 2003; Kushad et al., 1999).

Mean total glucosinolate concentrations in the leaves were higher in leafy and forage crops than in oilseed and root vegetables (Table 3 ). Forage crops had the highest progoitrin content $\left(10.10 \mu \mathrm{mol} \cdot \mathrm{g}^{-1} \mathrm{DW}\right)$, whereas leafy crops showed the highest glucobrassicanapin content $\left(11.08 \mu \mathrm{mol} \cdot \mathrm{g}^{-1} \mathrm{DW}\right)$. In previous studies, levels of progoitrin and glucobrassicin in nabicol and rutabaga crops were found to be lower than in the present study (Cartea et al., 2008; Font et al., 2005; Hopkins et al., 1998).

Glucobrassicanapin, a 5C glucosinolate (glucosinolate with a five-carbon side-chain), was the most abundant glucosinolate in the leaves of leafy and oilseed crops (46\% and $57 \%$ of the total glucosinolate content, respectively; Fig. 2A), followed by progoitrin (20\% and 14\%, respectively). In leaves of forage and root vegetable crops, progoitrin, a 4C glucosinolate (glucosinolate with a four-carbon side-chain), was the major glucosinolate $(42 \%$ and $36 \%$ of the total glucosinolate content, respectively; Fig. 2A), followed by glucobrassicanapin $(27 \%$ and $17 \%$, respectively). The most common indole glucosinolate in leaves of oilseed, leafy, and forage crops was glucobrassicin, which accounted for $3 \%, 5 \%$, and $6 \%$, respectively. Root vegetable crops contained a similar percentage $(8 \%)$ of glucobrassicin and neoglucobrassicin. Glucosinolate profile in rutabaga leaves was quite different with respect to the other groups (Fig. 2A). They contain the highest levels of neoglucobrassicin, as well as the highest gluconapoleiferin content, although this was not different from leafy crops. In contrast, they had the lowest glucobrassicanapin content. Glucobrassicanapin is the intermediate glucosinolate between glucoalyssin and gluconapoleiferin in the biosynthetic pathway of the $5 \mathrm{C}$ glucosinolates (Fig. 3). Differences on glucosinolate patterns among groups could indicate that the glucosinolate pathway in leaves of $B$. napus crops is regulated differently depending on each crop.
SEEDs. Significant differences were found among groups for all glucosinolates except for two indole glucosinolates (neoglucobrassicin and 4-methoxyglucobrassicin; Table 2). Location $\times$ group interaction differed significantly for the total glucosinolate content and for epi-progoitrin, sinigrin, and gluconapin glucosinolates. In the individual analysis by location, groups were significantly different for total glucosinolate content and for the three glucosinolates mentioned above at both locations, except for sinigrin at Valongo $(P<0.001)$. Seeds of $B$. napus in the forage group showed the highest total glucosinolate and gluconapin contents at both locations, whereas the oilseed cultivars had the lowest content for total and gluconapin glucosinolates (data not shown). Comparing the results from the individual analyses for these glucosinolates, groups with the extreme values were the same at both locations. Then, magnitude changes rather than rank changes contributed to the location $\times$ group interaction and means for all glucosinolates will be showed as a combination of both locations.

Mean total glucosinolate concentrations ranged from 54.67 $\mu \mathrm{mol} \cdot \mathrm{g}^{-1} \mathrm{DW}$ in the oilseed group to $114.66 \mu \mathrm{mol} \cdot \mathrm{g}^{-1} \mathrm{DW}$ in the forage group. Seeds of all groups have a high progoitrin content, which ranged from 30.11 to $71.57 \mu \mathrm{mol} \cdot \mathrm{g}^{-1} \mathrm{DW}$ in oilseed crops and root vegetable crops, respectively (Table 3 ). Forage crops showed the highest gluconapin content (30.17 $\left.\mu \mathrm{mol} \cdot \mathrm{g}^{-1} \mathrm{DW}\right)$, the second glucosinolate in abundance in the seeds. Oilseed crops had the lowest progoitrin and gluconapin contents, probably because they are commercial cultivars and selections to reduce the glucosinolate content in those genotypes have been performed.

In contrast to what happens in the leaves, the glucosinolate pattern found in the seeds was similar for the four groups (Fig. 2B). The main glucosinolates were two aliphatic glucosinolates: progoitrin and gluconapin. Progoitrin ranged from 54\% of the total glucosinolate content in the leafy cultivars to $66 \%$ in root vegetable cultivars, whereas gluconapin ranged from $20 \%$

Table 3. Total glucosinolate content in leaves and seeds of four groups of Brassica napus crops grown at two locations in northwestern Spain.

\begin{tabular}{|c|c|c|c|c|c|c|c|c|}
\hline \multicolumn{9}{|c|}{ Glucosinolate content $\left(\mu \mathrm{mol} \cdot \mathrm{g}^{-1} \mathrm{DW}\right)$} \\
\hline & \multicolumn{4}{|c|}{ Leaves } & \multicolumn{4}{|c|}{ Seeds } \\
\hline TOTAL & $23.98 \mathrm{a}$ & $24.00 \mathrm{a}$ & $14.22 \mathrm{~b}$ & $15.14 \mathrm{~b}$ & $114.66 \mathrm{a}$ & $96.53 \mathrm{c}$ & $54.67 \mathrm{~d}$ & $107.70 \mathrm{~b}$ \\
\hline PRO & $10.10 \mathrm{a}$ & $4.85 \mathrm{~b}$ & $2.04 \mathrm{c}$ & $5.46 \mathrm{~b}$ & $68.16 \mathrm{a}$ & $51.81 \mathrm{~b}$ & $30.11 \mathrm{c}$ & $71.57 \mathrm{a}$ \\
\hline EPI-PRO & $0.31 \mathrm{a}$ & $0.09 \mathrm{~b}$ & $0.04 \mathrm{~b}$ & $0.04 \mathrm{~b}$ & $1.56 \mathrm{a}$ & $1.24 \mathrm{~b}$ & $0.76 \mathrm{c}$ & $1.46 \mathrm{a}$ \\
\hline SIN & $0.09 \mathrm{a}$ & $0.08 \mathrm{a}$ & $0.02 \mathrm{a}$ & $0.02 \mathrm{a}$ & $0.66 \mathrm{a}$ & $0.30 \mathrm{~b}$ & $0.10 \mathrm{c}$ & $0.53 \mathrm{a}$ \\
\hline GAL & 1.41 & 1.78 & 1.26 & 1.88 & $1.22 \mathrm{~b}$ & $1.86 \mathrm{a}$ & $1.33 \mathrm{~b}$ & $1.26 \mathrm{~b}$ \\
\hline GNA & $2.29 \mathrm{a}$ & $2.68 \mathrm{a}$ & $1.37 \mathrm{~b}$ & $1.12 \mathrm{~b}$ & $30.17 \mathrm{a}$ & $23.91 \mathrm{~b}$ & $12.42 \mathrm{c}$ & $22.13 b$ \\
\hline GBN & $6.44 \mathrm{~b}$ & $11.08 \mathrm{a}$ & $8.05 \mathrm{~b}$ & $2.54 \mathrm{c}$ & $4.85 \mathrm{~b}$ & $8.08 \mathrm{a}$ & $4.26 \mathrm{~b}$ & $2.43 \mathrm{c}$ \\
\hline \multicolumn{9}{|l|}{ Indole } \\
\hline GBS & $1.43 \mathrm{a}$ & $1.27 \mathrm{a}$ & $0.47 \mathrm{~b}$ & $1.16 \mathrm{a}$ & $0.21 \mathrm{~b}$ & $0.39 \mathrm{a}$ & $0.16 \mathrm{~b}$ & $0.15 \mathrm{~b}$ \\
\hline OHGBS & 0.06 & 0.10 & 0.03 & 0.21 & $5.51 \mathrm{a}$ & $5.53 \mathrm{a}$ & $4.05 \mathrm{~b}$ & $5.61 \mathrm{a}$ \\
\hline
\end{tabular}

Means in rows followed by the same letter are not significantly different at $P \leq 0.05$.

${ }^{\mathrm{z}} \mathrm{PRO}=$ progoitrin, EPI-PRO $=$ epiprogoitrin, SIN = sinigrin, GNL = gluconapoleiferin, GAL = glucoalyssin, GNA $=$ gluconapin, GBN $=$ glucobrassicanapin, GBS = glucobrassicin, OHGBS = 4-hydroxyglucobrassicin, NGBS = neoglucobrassicin, MetGBS = 4methoxyglucobrassicin, and GNS = gluconasturtiin.

${ }^{\mathrm{y}}$ Not detected in leaves. 
A

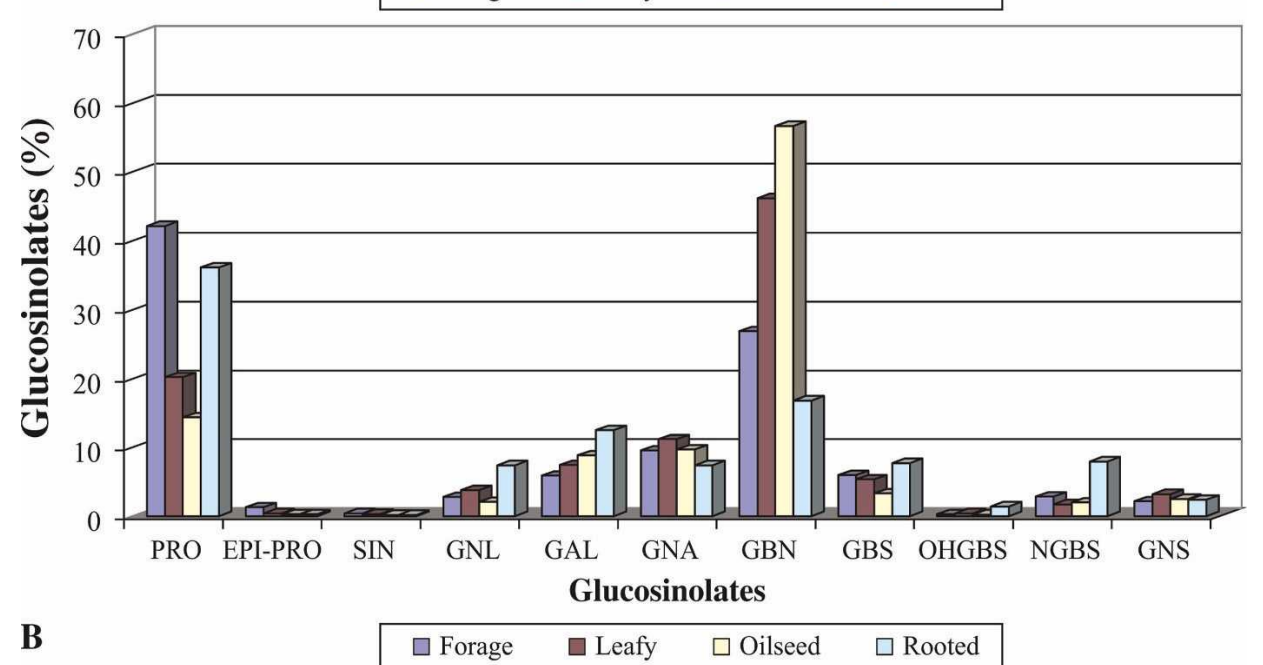

B

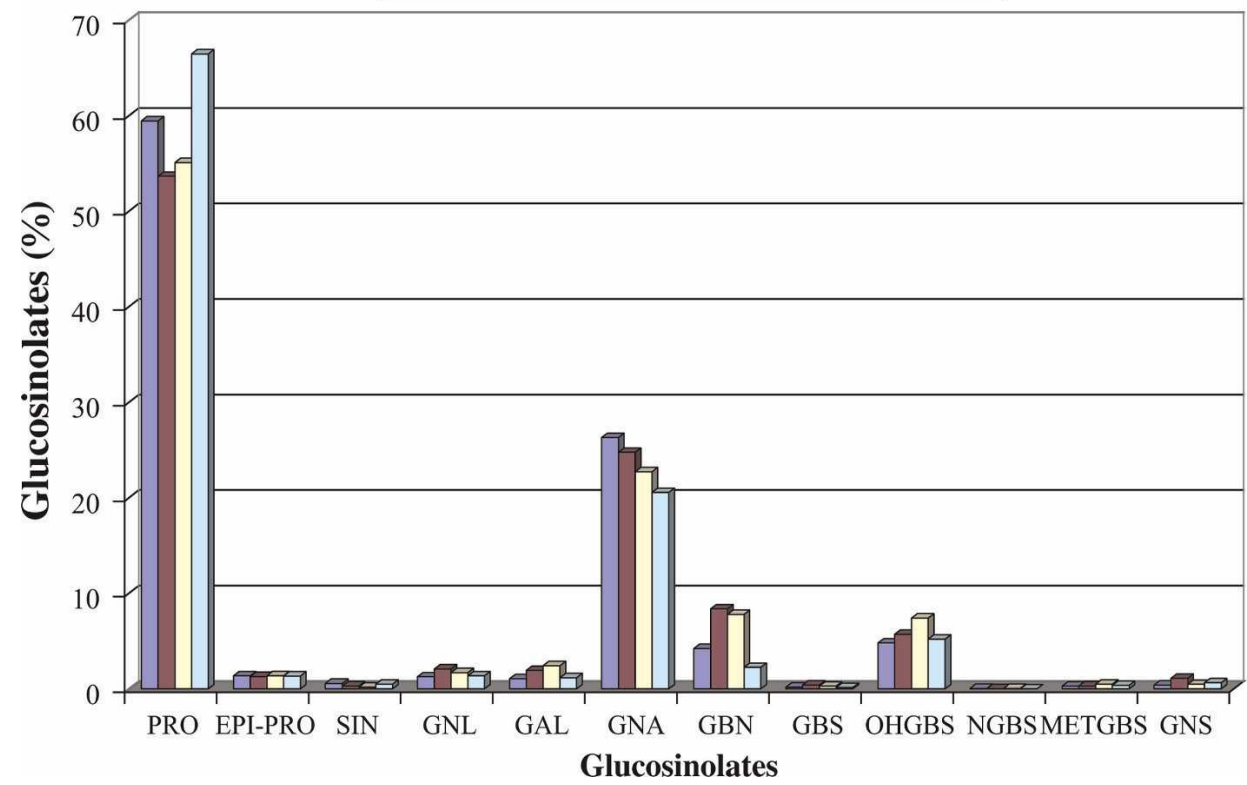

Fig. 2. (A) Percentage of glucosinolates in leaves of four groups of Brassica napus crops grown at two locations in northwestern Spain. (B) Percentage of glucosinolates in seeds of four groups of Brassica napus crops grown at two locations. $\mathrm{PRO}=$ progoitrin, $\mathrm{EPI}-\mathrm{PRO}=$ epiprogoitrin, $\mathrm{SIN}=$ sinigrin, $\mathrm{GNL}=$ gluconapoleiferin, $\mathrm{GAL}=$ glucoalyssin, GNA = Gluconapin, GBN = glucobrassicanapin, GBS = glucobrassicin, OHGBS = 4-hydroxyglucobrassicin, NGBS = neoglucobrassicin, MetGBS $=4$ - methoxyglucobrassicin, and GNS = gluconasturtiin .

in root vegetable crops to $26 \%$ in forage crops. Indole and aromatic glucosinolates were minor (less than $10 \%$ of the total glucosinolate content). The major indole glucosinolate was 4-hydroxyglucobrassicin (5\% in leafy crops to $7 \%$ in oilseed crops) and a small amount of 4-methoxyglucobrassicin, absent in the leaves, was found in the seeds. Only traces of neoglucobrassicin were found. The aromatic glucosinolate gluconasturtiin represented among $0.5 \%$ to $1 \%$ in seeds, considerably less than in leaves $(2 \%-3 \%$ in different groups).

In $B$. napus seeds, $4 \mathrm{C}$ glucosinolates are the most abundant and the accumulation of specific $4 \mathrm{C}$ did not change according to the crop. Progoitrin and gluconapin are the final products in the synthesis pathway of the $4 \mathrm{C}$ glucosinolate where their precursor, glucoraphanin, a glucosinolate that attracts much attention nowadays because of its association with anticarcinogenic activity, (Mi et al., 2007) was not found.
Previous studies found similar glucosinolate patterns in leaves and seeds of B. napus crops, although some variation has been found depending on the crop cultivar: progoitrin and gluconapoleiferin have been reported as predominate glucosinolates in rapeseed (Fenwick et al., 1983), and indole glucosinolates have also been reported as common constituents in forage rape. In line with our results, glucobrassicanapin, progoitrin, and gluconapin were found to be the dominant compounds in nabicol, couvenabiça, and rutabaga leaves (Cartea et al., 2008; Font et al., 2005; Griffiths et al., 2001; Rosa et al., 1996).

Depending on the concentrations of the glucosinolates and degradation products, B. napus crops can have antinutritional or positive physiological effects. These effects are linked not only to the types of glucosinolates present, but also to what is the acceptable intake level for a particular animal species. Progoitrin has been considered as antinutritional glucosinolate because its goitrogenic effects (Anilakumar et al., 2006; Laurberg et al., 2002) and although this unfavorable effect has been not reported in human consumption, cultivars with low progoitrin content should be selected. Indeed, isothiocyanates derived from the hydrolysis of gluconapin can reduce the palatability of products such as rape meal. These reasons have led to attempts to reduce or eliminate glucosinolates in crops such as oilseed rape. In this study, the local cultivars used as leafy crops in human consumption (nabicol or couve-nabiças) had the lowest progoitrin levels $\left(4.8 \mu \mathrm{mol} \cdot \mathrm{g}^{-1} \mathrm{DW}\right)$ in the leaves along with the commercial cultivars of rapeseed $\left(2 \mu \mathrm{mol} \cdot \mathrm{g}^{-1}\right.$ DW; Table 3, Fig. 2A). In the seeds, oilseed rape crops showed glucosinolate levels considerably reduced, particularly for progoitrin and gluconapin (Table 3, Fig. 2B). Oilseed cultivars included in this study are commercial cultivars and some selection for low glucosinolate content in the seeds could have occurred even though the seed glucosinolate content was higher than levels of current commercial cultivars of oilseed rape, which contain less than $30 \mathrm{mmol}$ of glucosinolates per gram of meal.

Glucosinolate content can be altered in response to environmental conditions and may also vary with the development stage of the plant (Rosa et al., 1997; Velasco et al., 2007). It has also been reported that the glucosinolates present in the seed and vegetative tissues of brassica plants may vary 
chain elongation $3 \mathrm{C}$ Methionine

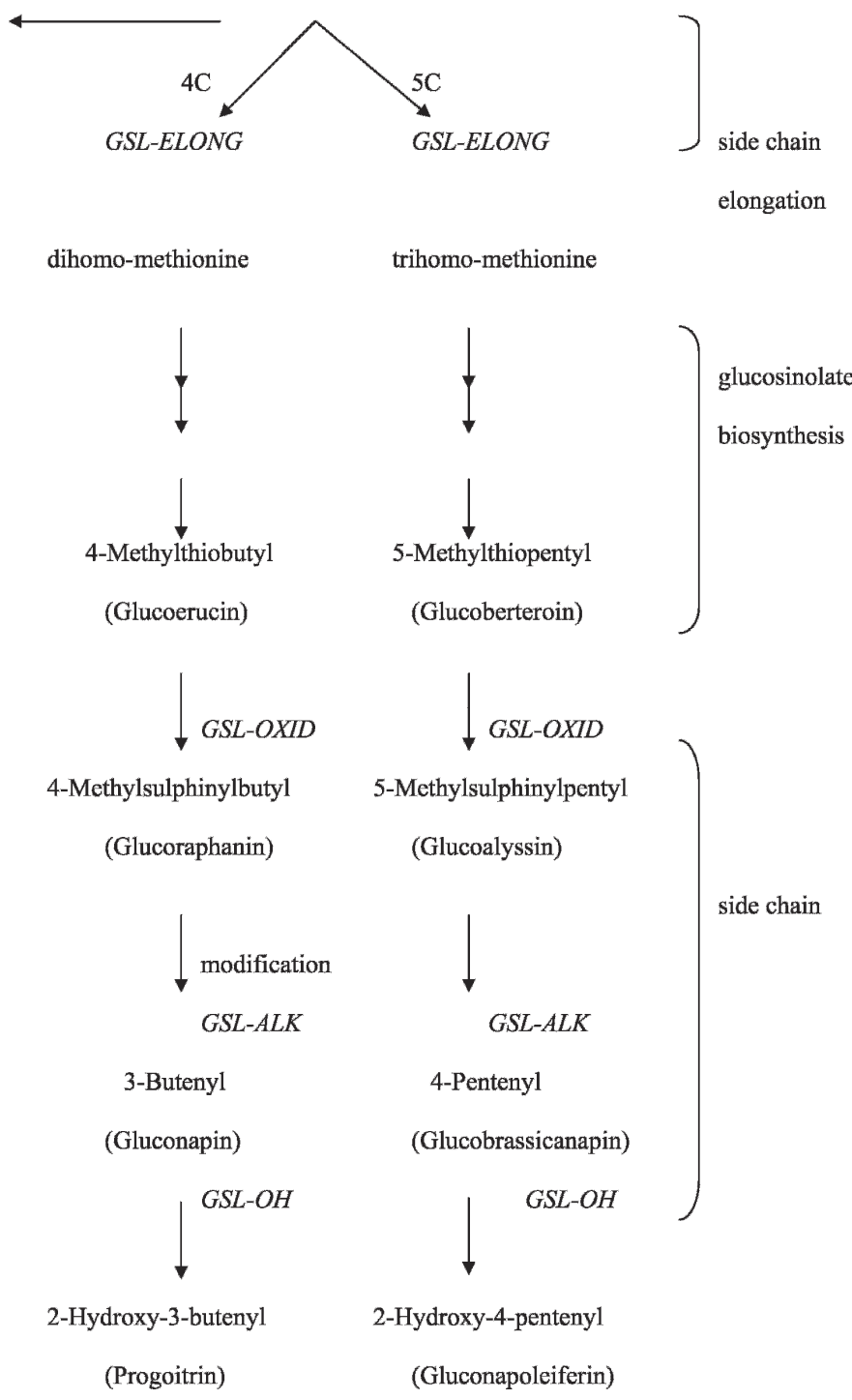

Fig. 3. A biochemical genetic model of aliphatic glucosinolates biosynthesis, including the major genes controlling this process in Brassica napus (Halkier and $\mathrm{Du}, 1997) .3 \mathrm{C}, 4 \mathrm{C}$, and $5 \mathrm{C}=$ glucosinolate with a three-carbon, fourcarbon, and five-carbon side chain, respectively.

independently of each other. Generally, glucosinolate levels in the seeds have been reported to be higher than in the leaves, stems, and roots (Rosa et al., 1997). In our study, the total glucosinolate content in seeds was between 3.8- (oilseed crops) and 7.1-fold (root vegetable crops) higher than levels in leaves. Previous studies have suggested that glucosinolates produced in the vegetative tissues of brassica plants were unlikely to correlate significantly with glucosinolate accumulation in seeds (Fieldsend and Milford, 1994; Li et al., 1999). For example, glucosinolate levels were similar in the foliage of single-low (zero erucic acid) and double-low (zero erucic acid and low glucosinolate levels) oilseed rape cultivars, whereas glucosinolate concentration in seeds of these two lines differed significantly (Rosa et al., 1997). A recent study showed variation in glucosinolate composition in different organs of arabidopsis (Brown et al., 2003) at different development stages during its life cycle, which supports the idea that the expression of genes related to glucosinolate production are independently regulated in seeds and leaf tissue. In this study, correlations among glucosinolates in seeds and leaf tissue were low to moderate. The correlations among total glucosinolate concentration, progoitrin, glucoalissyn, glucobrassicanapin, and gluconasturtiin in leaves and seeds were $0.53,0.71,0.65$, 0.58 , and $0.58(P<0.01)$, which means that glucosinolate production in both tissues are not totally independent.

The biosynthetic relationships between aliphatic glucosinolates present in B. napus are shown in Fig. 3, as reviewed by Halkier and Du (1997). Qualitative differences observed among aliphatic composition may be due to allelic variation in a few genes encoding key regulatory enzymes at key points in the glucosinolate pathway. Aliphatic glucosinolates are classified by side-chain size as three-carbon (3C), 4C, and 5C. In B. napus leaves, $4 \mathrm{C}$ and $5 \mathrm{C}$ glucosinolates are the most abundant. However, the accumulation of specific $4 \mathrm{C}$ and $5 \mathrm{C}$ glucosinolates in leaves varied according to the crop, and two different glucosinolate profiles were found, one characterized by high progoitrin and the other containing high glucobrassicanapin content. The different selection criteria applied on B. napus crops could have led to an indirect selection for glucosinolate profile in leaves.

The results obtained could support the idea that selection applied based on the final product of each crop could have led to an indirect selection for either glucosinolate profile or content in the leaves of these B. napus crops, but not in the seeds. Differences in glucosinolate profiles among the crops could suggest the possibility of using them as genetic markers, as was pointed out by others (Heaney and Fenwick, 1980; Rosa, 1997), but further research using different cultivars with the same end use is needed to confirm this finding.

\section{Literature Cited}

Anilakumar, K.R., F. Khanum, and A.S. Bawa. 2006. Dietary role of glucosinolate derivatives. J. Food Sci. Technol. 43:8-17.

Brown, P.D., G.J. Tokuhisa, M. Reichelt, and J. Gershenzon. 2003. Variation of glucosinolate accumulation among different organs and developmental stages of Arabidopsis thaliana. Phytochemistry 62:471-481.

Cartea, M.E. and P. Velasco. 2008. Glucosinolates in Brassica foods: Bioavailability in food and significance for human health. Phytochem. Rev. (in press). DOI: 10.1007/s11101-007-9072-2.

Cartea, M.E., V.M. Rodríguez, A. de Haro, P. Velasco, and A. Ordás. 2008. Variation of glucosinolates and nutritional value in nabicol (Brassica napus pabularia group). Euphytica 159:111-122.

Cartea, M.E., P. Soengas, A. Picoaga, and A. Ordás. 2005. Relationships among Brassica napus (L.) germplasm from Spain and Great Britain as determined by RAPD markers. Genet. Resources Crop Evol. 52:655-662.

Fahey, J.W., A.M. Zalcmann, and P. Talalay. 2001. The chemical diversity and distribution of glucosinolates and isothiocyanates among plants. Phytochemistry 56:5-61.

Fenwick, R.G., R.K. Heaney, and W.J. Mullin. 1983. Glucosinolates and their breakdown products in food plants. CRC Crit. Rev. Food Sci. Nutr. 18:123-201.

Fieldsend, J. and G.F.J. Milford. 1994. Changes in glucosinolates during crop development in single- and double-low genotypes of winter oilseed rape (Brassica napus): Production and distribution in vegetative tissues and developing pods during development and potential role in the recycling of sulphur within the crop. Ann. Appl. Biol. 124:531-542.

Font, R., M. del Río, M.E. Cartea, and A. de Haro. 2005. Application of near-infrared spectroscopy to the analysis of total and individual glucosinolates in Brassica napus leaves. Phytochemistry 66:175-185. 
Griffiths, D.W., A.N.E. Birch, and J.R. Hillman. 1998. Antinutritional compounds in the Brassicaceae: Analysis, biosynthesis, chemistry and dietary effects. J. Hort. Sci. Biotechnol. 73:1-18.

Griffiths, D.W., N. Deighton, A.N. Birch, B. Patrian, R. Buar, and E. Stadler. 2001. Identification of glucosinolates on the leaf surface of plants from the Cruciferae and other closely related species. Phytochemistry 57:693-700.

Halkier, B.A. and L. Du. 1997. The biosynthesis of glucosinolates. Trends Plant Sci. 2:425-431.

Heaney, R.K. and G.R. Fenwick. 1980. The glucosinolate content of Brassica vegetables: A chemotaxonomic approach to cultivar identification. J. Sci. Food Agr. 31:794-801.

Hopkins, R.J., D.W. Griffits, A.N.E. Birch, and R.G. McKinlay. 1998. Influence of increasing herbivore pressure on modification of glucosinolate content of swedes (Brassica napus ssp. rapifera). J. Chem. Ecol. 24:2004-2019.

Kim, S.J., S. Kawaguchi, and Y. Watanabe. 2003. Glucosinolates in vegetative tissues and seeds of twelve cultivars of vegetable turnip rape (Brassica rapa L.). Soil Sci. Plant Nutr. 49:337-346.

Kliebenstein, D.J., J. Kroymann, P. Brown, A. Figuth, D. Pedersen, J. Gershenzon, and T. Mitchell-Olds. 2001. Genetic control of natural variation in Arabidopsis glucosinolate accumulation. Plant Physiol. 126:811-825.

Kushad, M., A. Brown, A. Kurilich, J. Juvik, B. Klein, M. Wallig, and E. Jeffery. 1999. Variation of glucosinolate in vegetable crop of Brassica oleracea. J. Agr. Food Chem. 47:1541-1548.

Lambrix, V., M. Reichelt, T. Mitchell-Olds, D.J. Kliebenstein, and J. Gershenzon. 2001. The Arabidopsis epithiospecifier protein promotes the hydrolysis of glucosinolates to nitriles and influences Trichoplusia ni herbivory. Plant Cell 13:2793-2807.

Laurberg, P., S. Andersen, N. Knudsen, L. Ovesen, S.B. Nohr, and I.B. Pedersen. 2002. Thiocyanate in food and iodine in milk: From domestic animal feeding to improved understanding of cretinism. Thyroid 12:897-902.

Li, Y., G. Kiddle, R. Bennet, K. Doughty, and R. Wallsgrove. 1999. Variation in the glucosinolate content of vegetative tissues of
Chinese lines of Brassica napus L. Ann. Appl. Biol. 134:131136.

Mi, L.X., X.T. Wang, S. Govind, B.L. Hood, T.D. Veenstra, T.P. Conrads, D.T. Saha, R. Goldman, and F.L. Chung. 2007. The role of protein binding in induction of apoptosis by phenethyl isothiocyanate and sulforaphane in human non-small lung cancer cells. Cancer Res. 67:6409-6416.

Mithen, R. 2001. Glucosinolates and their degradation products. Adv. Bot. Res. 35:213-262.

Rodríguez, V.M., M.E. Cartea, G. Padilla, P. Velasco, and A. Ordás. 2005. The nabicol: A horticultural crop in northwestern Spain. Euphytica 142:237-246.

Rosa, E.A.S. 1997. Glucosinolates from flower buds of Portuguese Brassica crops. Phytochemistry 44:1415-1419.

Rosa, E.A.S., R.K. Heaney, and C.A.M. Portas. 1996. Changes in glucosinolate concentrations in Brassica crops (B. oleracea and B. napus) throughout growing seasons. J. Sci. Food Agr. 71:237-244.

Rosa, E.A.S., R.K. Heaney, G.R. Fenwick, and C.A.M. Portas. 1997. Glucosinolates in crop plants. Hort. Rev. (Amer. Soc. Hort. Sci.) 19:99-215.

Soengas, P., M.E. Cartea, P. Velasco, G. Padilla, and A. Ordás. 2008. Morphologic and agronomic diversity of Brassica napus crops. J. Amer. Soc. Hort. Sci. 133:48-54.

Steel, R.D.G., J.H. Torrie, and D.A. Dickey. 1997. Principles and procedures in statistics: A biometrical approach. 3rd ed. McGraw Hill, New York.

Velasco, P., M.E. Cartea, C. González, M. Vilar, and A. Ordás. 2007. Factors affecting the glucosinolate content of kale (Brassica oleracea acephala group). J. Agr. Food Chem. 55:159-165.

Wathelet, J.P., P. Wagstaffe, and A. Boenke. 1991. The certification of the total glucosinolate and sulphur contents of three rapeseeds (colza), CRMs 190, 366 and 367. Commission of the European Communities Rpt. EUR13339 EN.

Wittstock, U. and J. Gershenzon. 2002. Constitutive plant toxins and their role in defense against herbivores and pathogens. Curr. Opin. Plant Biol. 5:300-307. 